\title{
EXAMINING NON REVENUE WATER: A CASE STUDY OF AHMEDABAD
}

\author{
Vibhore Bakshi ${ }^{1}$ \\ ${ }^{1}$ Assistant Professor, Architecture and Planning Department, Amity University, Gurgaon
}

\begin{abstract}
Ahmedabad has a population of 62 lakhs of which 78 percent resides within the municipal area. The rapid urbanization has led to overflow of population outside the city limits which has resulted in an increasing demand of water. The paper attempts to examine the non-revenue water in context of Ahmedabad it throws light on the present water supply in Ahmedabad and instigates the amount of non-revenue water which majorly include physical losses, commercial losses and unbilled authorized consumption. After instigating $N R W$, the solutions are recommended for the locations with higher percentage of Non-Revenue water.
\end{abstract}

Keywords: Increasing demand of water, Non-Revenue water, Physical losses, Water supply

\section{INTRODUCTION}

The urban water supply in India is characterised by inadequate coverage, intermittent supply, outdated piping, low pressure and poor quality. Chronic shortage of investments and inadequate operation and maintenance are the major contributing factors. Although the water supply system is inadequate, lack of maintenance and inadequate replacement leads to losses in distribution. Metering errors, water theft and unbilled collection also lead to high levels of Non-Revenue Water (NRW). Moreover the unwillingness of local/state governments to levy proper user charges to the service provided also lead to poor performance. Water boards in India area able to recover only 30 to 35 per cent of the operation and maintenance (O\&M) cost (HPEC, 2011).

In India, where water is treated as a most basic and natural good, the ability to pay for water provision is very limited. Water wasted through losses in the supply and distribution system may provide an opportunity for water boards, and if well managed, the water saved from various leakages and thefts could be redistributed to areas not receiving sufficient water supplies, hence resulting in improved revenues with comparatively lesser investments.

Effective Management of Non-Revenue water (NRW) could be one of the possible solutions for improving the finances of ULBs. NRW management has multiple benefits, if well managed it leads to efficient resource utilization, efficient utility management, enhanced consumer satisfaction, and postponement of capital-intensive additions to capacity (Frauendorfer and Liemberger, 2010).

\subsection{Objectives}

- To review the existing scenario of water supply in Ahmedabad

- To examine the Non-revenue water in the selected locations of Ahmedabad
- To provide a solution for reducing NRW in the selected locations with a higher percentage

\subsection{Research Methodology}

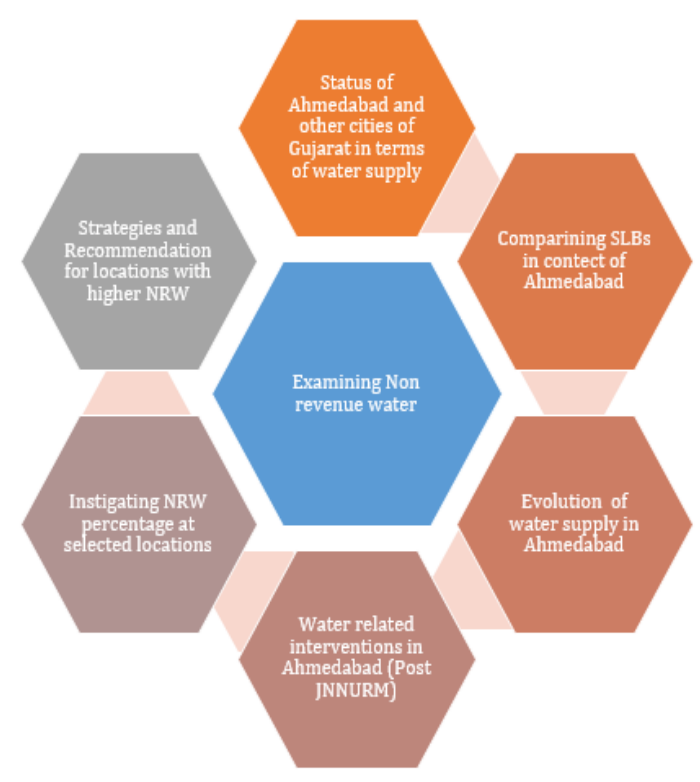

\section{LITERATURE REVIEW}

\subsection{Government of India Initiative}

A number of programs were launched in the past few years for improving water supply (and sanitation) services including the Accelerated Urban Water Supply Program (AUWSP), the Jawaharlal Nehru National Urban Renewal Mission (JNNURM), the Urban Infrastructure Development Scheme for Small and Medium Towns (UIDSSMT) and various states governments programs for improving urban water and sanitation services 
Table-1: Investment in different sectors

\begin{tabular}{|l|l|l|}
\hline S.No & Sector & $\begin{array}{l}\text { Investment as of Dec } \\
\mathbf{2 0 1 0}(\boldsymbol{\%})\end{array}$ \\
\hline 1 & $\begin{array}{l}\text { Road and Urban } \\
\text { Transport }\end{array}$ & 24 \\
\hline 2 & Urban Renewal & 1 \\
\hline 3 & Water supply and & 41 \\
\hline 4 & $\begin{array}{l}\text { Sewerage } \\
\text { Sanitation }\end{array}$ & 3 \\
\hline 5 & SWM & 12 \\
\hline 6 & Drainage & \\
\hline
\end{tabular}

Source: $H P E C, 2011$

Until the initiation of Jawaharlal Nehru National Urban Renewal Mission (JNNURM) in 2005, little attention was given for the improvement of water supply infrastructure of Indian cities. Water sector constitutes highest number in terms of funding (40\%) and also the number of projects executed (HPEC, 2011). The water supply indicators are: 'coverage of water supply connections'; 'per capita supply of water'; 'extent of metering of water connections'; 'extent of non-revenue water'; 'continuity of water supply'; 'quality of water supplied'; 'efficiency in redressal of customer complaints'; 'cost recovery in water supply services'; and 'efficiency in collection of water supply-related charges'.

\subsection{Non-Revenue Water}

- Non-Revenue Water (NRW) is defined as the difference between the amount of water put into the distribution system and the amount of water billed to consumers (ADB 2010).

- 40 to 70 percent of more water can be available to the urban households without any extra cost by reducing financial and physical losses. (World Bank,2012)

- To increase the supply capacity, investment in NRW reduction will be much cost effective than investments in new capital projects. (Liemberger, 2010)

- The per unit cost of reducing leakages is significantly less than the cost involved in creating additional capacity (PwC, 2011)

- Hence focus on NRW management may be a sustainable model of urban water management.

- $\quad$ NRW = System Input Volume -Billed Authorized Consumption

- According to International Water Association (IWA) NRW has the following components:

\section{- Physical (or real) losses}

Leakages from transmission mains, storage facilities, distribution mains or service connections. They are majorly caused due to poor operation and maintenance and poor quality of underground materials (assets).

\section{- Commercial (or apparent) losses}

Caused due to water theft, metering inaccuracies and poor data holdings. Significance of Non-Revenue Water in Urban Water Management

- Unbilled authorized consumption Water which cannot be billed like firefighting purposes and free water services to certain groups. The level of Non-Revenue Water in India is extremely high, it is estimated that NRW in India range between $40 \%-60$ $\%$ or even higher. Even this is a guesstimate, as majority of Indian cities do not have real accounting system for the water that is actually supplied to various consumers (HPEC, 2011, Planning Commission of India, 2011 and Mckinsey Global Institute, 2012).

\subsection{Why is NRW not being addressed?}

Very little interest and attention is shown in addressing the issue of NRW by the water utilities after knowing the potential benefits that NRW provides. Evidences of simple management and technical issues by some water utilities have resulted in dramatic results in reducing the water losses (e.g., Phnom Penh, Manila, Singapore). The major reasons include:

Asset Management. A lack of understanding of the link between asset management and NRW and how good asset management practices will address not only the amount of water lost but also the underlying cause of NRW.

Capacity. The ULBs lack in Lack in technical expertise and equipment.

Awareness. ULBs, government officials and public often are unaware of the quantum of water loss in the system and also the benefits of reducing NRW.

Funding. NRW reduction is seen as an operational activity, which is usually covered by an inadequate budget for operation and maintenance

Accounting. NRW does not explicitly appear in the financial statements of a public service, so that public services, their owners, and the public are not aware of the value of the amount of water you really lose each month. Yet, they still have to cover all costs of production and distribution, which is transmitted to the paying customers.

Raw water pricing. Grant or absence of raw water pricing. If utilities have to pay for the raw water used, they (most likely) be more careful handling and avoid unnecessary losses. Significance of Non-Revenue Water in Urban Water Management

\subsection{Overview of Cities of Gujarat}

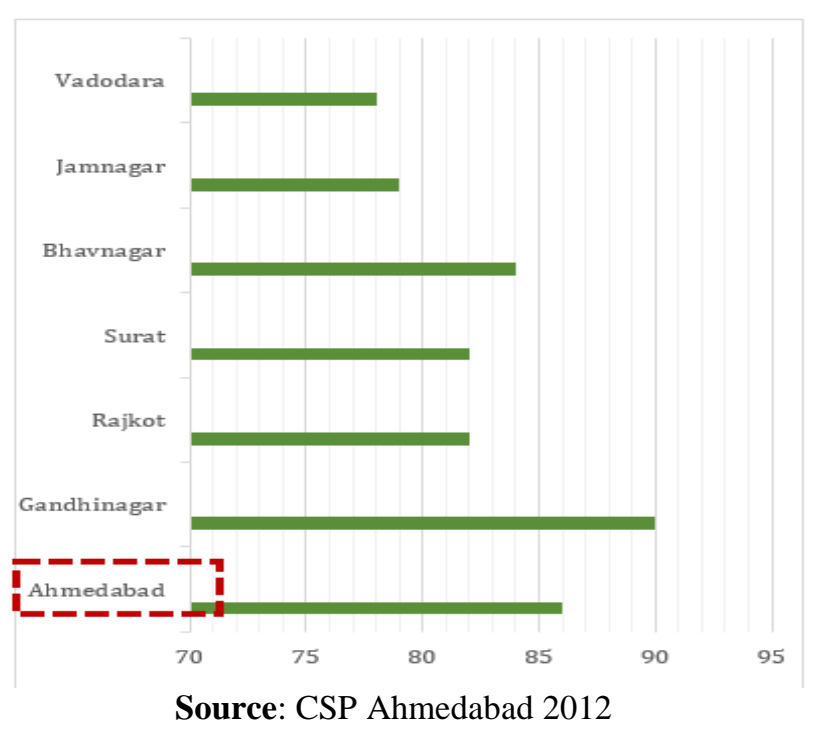

Graph 1: Water supply coverage of cities in Gujarat 
In terms of coverage of water supply Ahmedabad is doing well and is placed at second position as compared to other cities in Gujarat with a coverage of 86 percent household which is placed behind Gandhinagar that is one of the planned cities in India. Whereas in comparison other cities like Rajkot,Surat, Bhavnagar,Jamnagar and Vadodara are behind. Although coverage of water supply is good but if we compare all the indicators stated under Service level benchmarking for Ahmedabad "extent of NRW" have increased over the years

\subsection{Comparison of Service Level Benchmarks over the}

\section{Years}

In terms of the indicators listed above Ahmedabad's extent of non-revenue water is more than what it is listed under service level benchmarks by MOUD. For three indicators mentioned below. We don't have metering of water connections and secondly extent of NRW has increased In comparison to other indicators Ahmedabad is doing well but Non-revenue water is a major concern for the Ahmedabad Municipal Corporation and the people of Ahmedabad

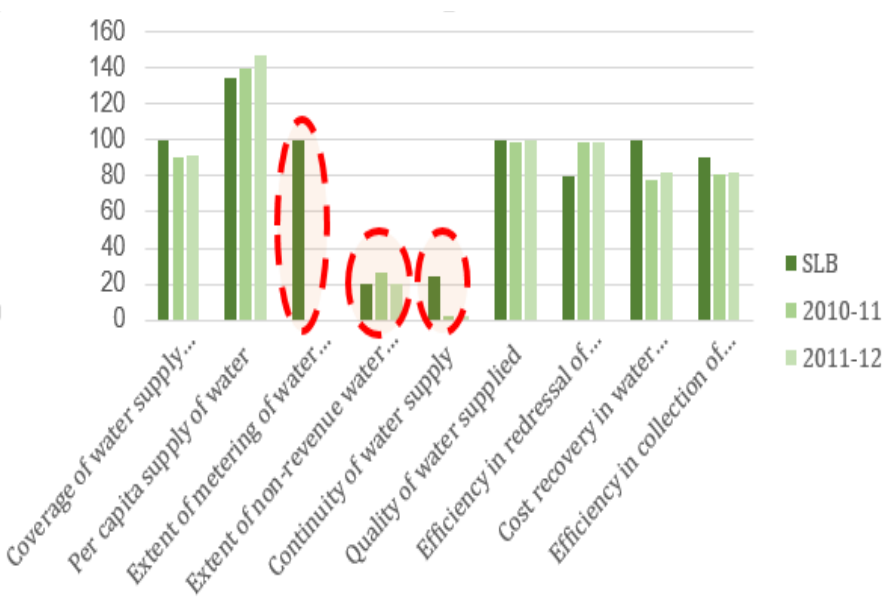

Source: CSP Ahmedabad 2012

Graph 2: Comparison with Service level benchmarks

\section{AHMEDABAD AT A GLANCE}

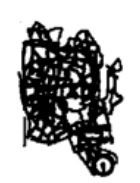

1890

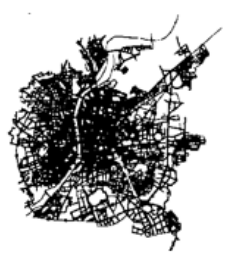

1979

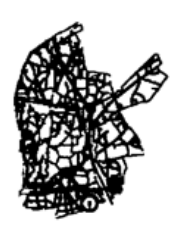

1931

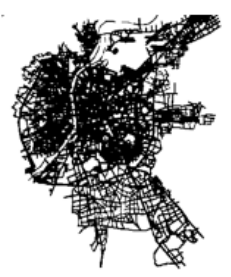

1997
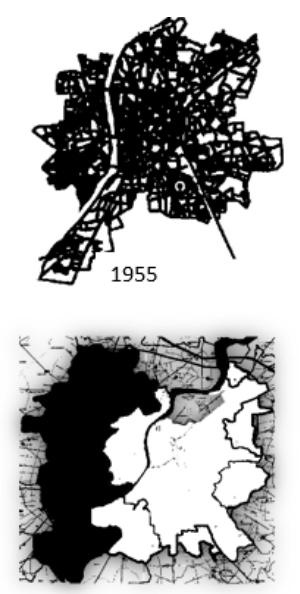

2012
The origin of Ahmedabad's water network started from 1890 when water was tapped from Dholka branch of Sabarmati and Dudeshwar water works started in 1891 in which water from Narmada was tapped and the water network of city grew in east zone till 1931 and later on the water network expanded to east and west zone by 1955 . As the population was increasing in east and west zone thus to cater the needs of people kotarpur water work started in 1970 which at present supplies water to majority of Ahmedabad population. The water distribution network further expanded to south zone by 1997 and later on after 2006 city's water distribution network grew in New west zone.

\subsection{Water Zones in Ahmedabad}

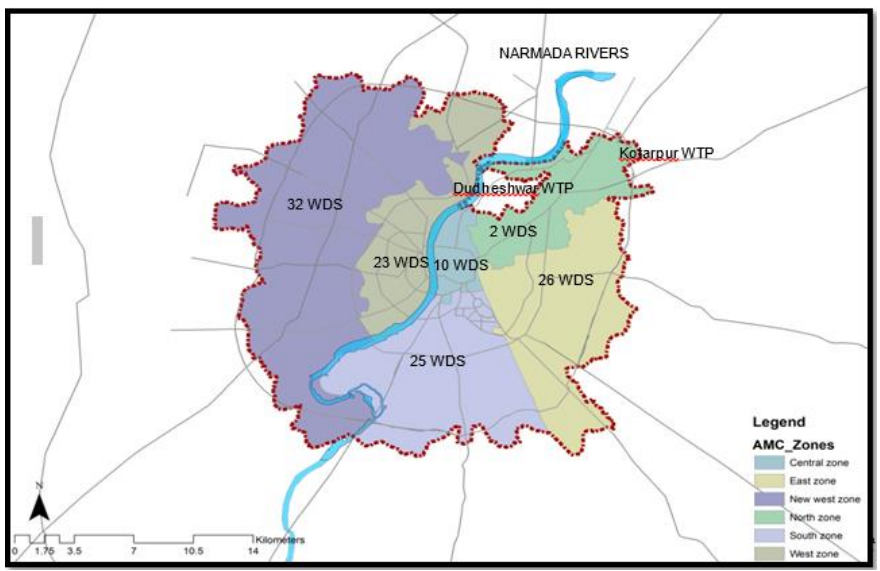

Source: PAS Report,2012

Ahmedabad Municipal Corporation has 139 water distribution stations across the city. There are six distribution zones, overlapping with the administrative zones. The distribution network of $3500 \mathrm{~km}$ covers entire city. The length of trunk main line is about $230 \mathrm{~km}$. The average daily supply of water is around 1030 MLD. The average litre per capita per day (lpcd) is estimated around 148 LPCD. The coverage of water supply connection is reported to be 88.3 percent 1 . The daily supply of water at consumer end is $2.25 \mathrm{Hrs}$ on fixed time

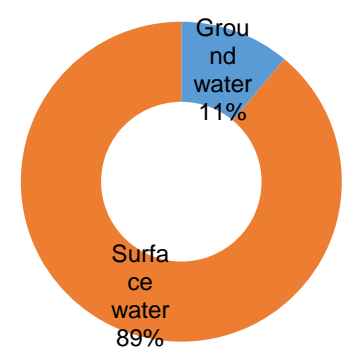

Source: PAS, 2012

Pie 1: Comparison with Service level benchmarks

The major water source for Ahmedabad's population is surface water and few people rely on ground water. The source for getting water which has changed over the decades.

Source: CSP Ahmedabad 2012 


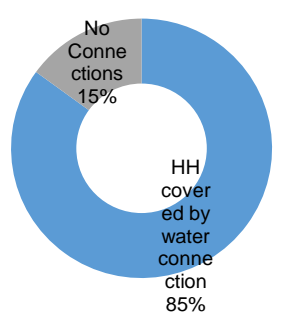

Source: $P A S, 2012$

Pie 2: Water Connections in Ahmedabad

According to city sanitation plan for Ahmedabad. The total water produce is $1215 \mathrm{MLD}$, out of which $135 \mathrm{MLD}$ is extracted from ground water as a source and remaining 1080 MLD from surface as a source for a single day. The dependency of Ahmedabad's population on ground water have decreased over the years.

Majority of households are covered by municipal water connections whereas few people are devoid of municipal water supply. The reason could be these households are located on the periphery or outside the corporation boundary of Ahmedabad. These households are result of urban outgrowth and are yet to be covered by municipal water supply. The interrogation in the process is how these 15 percentage of the population get water supply, a possible scenario could be the thefts or illegal connections. Another aspect could be the provision of water supply through municipal trucks, tractors etc. In this research we will identify the amount of unaccounted water in terms of non-revenue water

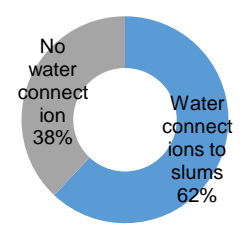

Source: CSP, 2012

Pie 3: Water Connections in Slums

It is interesting to know that out of 15 percent of Nonconnections majority of them i.e. 38 percent are a part of slums. Nearly 38 percent of slums are not covered by municipal water supply which means that either municipal trucks or tankers supply water to the 38 percentage of population or there is a possibility of thefts or illegal connection that may result in an increase in Non-revenue water.

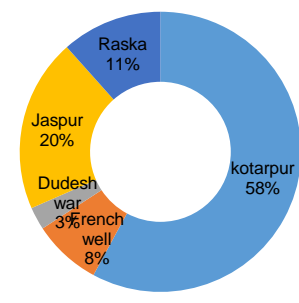

Source: CSP, 2012

Pie 4: Actually treated water

Out of overall 1620 MLD capacity 950 MLD is actually treated. 550MLD of water is treated at Kotarpur treatment plan followed by other treatment plants with their treatment capacities. French Wells=75MLD

- Dudeshwar WTP=25MLD

- Jaspur WTP=190MLD

- Raska WTP=110 MLD

Once the water is treated it goes to reservoirs intake structures. These intake structures can be classified in to two types' i.e. overhead intake structures and Underground intake structures All treated water goes to these intake structures. In terms of capacity of the reservoirs, water underground reservoirs serve as the major source for the Ahmedabad's population which have a capacity of 857.4MLD .There are 141 Overhead tanks which possess a capacity of total 62.69 MLD.

\subsection{Water Prospects in Ahmedabad}

The population of Ahmedabad is increasing and the demand for water is also increasing therefore there is a need to focus on augmentation of new water sources to cater the needs of growing population or to improvise the existing water distribution system by including smart techniques that may result in a decline of NRW .To know the demand of water and to cope up with future needs it is essential to look the present needs as well as future requirement of water. For this we have estimated the water for different decades. 


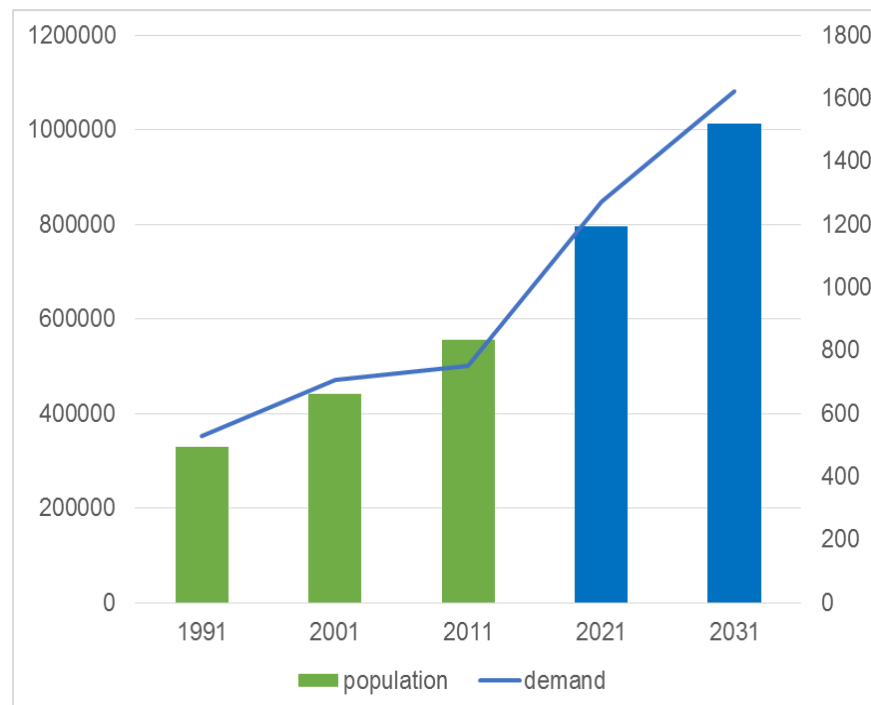

Source: Census of India

Graph 3: Population and Water demand for Ahmedabad

This graph shows the major concern for the citizens of the Ahmedabad .The water demand increases from 1991 to 2001 and the rate decreases from 2001 to 2011.But from 2011 to 2031 there is a sharp increase of water demand as the population will increase in the future years. There is a sharp rise in the water demand of Ahmedabad from 2011 to 2031 which can be provided either by augmenting new water sources or by reducing illegal tapping or Unaccounted for water. Current average daily supply of water is 1030MLD and the forecasted water requirement by 2031 would be 1623 MLD thus provision of water supply shall be a serious concern for the population of Ahmedabad.

\subsection{Water Related Interventions in Ahmedabad}

But a very little attention is given towards water sectors which can be examined from the pie diagram.Out of 1000 crores sanctioned to AMC only 86 crores is sanctioned for water sector which shows that an important emphasis is given on all other sectors rather than water sector

Although 86 crores were sanctioned under JNNURM for water related interventions

- 40 crores for $24 * 7$ water supply in Jodhpur, new west zone , Ahmedabad

- 13.58 crores $24 * 7$ water supply at Navrangpura, Stadium, Juna Vadaj

- 33.3 crores for Automation (SCADA based) of the Water Supply System
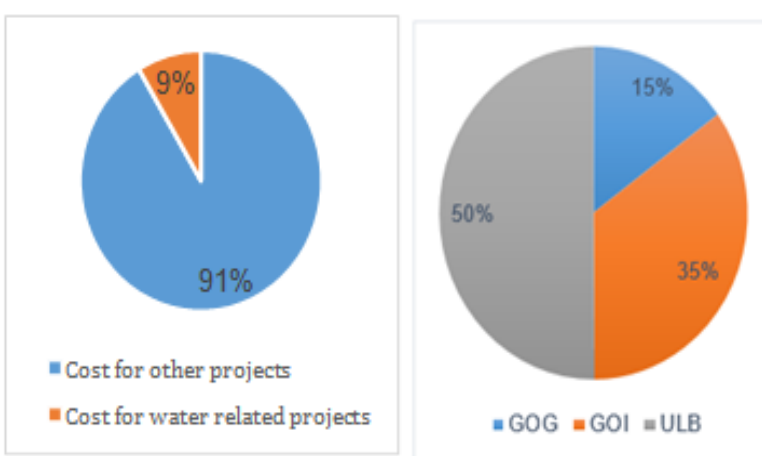

Source: CSE India.org

Pie 5: water related investment

Pie 6: Share of Government

If we look at the share of government, we can examine that $\mathrm{AMC}$ is a major contributor in all types of projects. For any interventions under AMC jurisdiction it spend more and it shows that municipal corporation has a good revenue base in terms of collection of user charges, taxes etc.

\section{ANALYSIS AND RECOMMENDATIONS}

\subsection{Calculating NRW through bucket survey}

40 samples were taken from the core areas of Ahmedabad like kalupur and Maninagar along with Newly developed areas Bokadev and SP stadium. Surveys were conducted

- How much water these households get from municipal corporation supply in a day?

- What are the sources of water supply in these locations?

- How much water is supplied through OHT and Underground reservoirs?

- What is the duration of water supply?

Table 2: Attributes for demand and supply

\begin{tabular}{|l|l|}
\hline $\begin{array}{l}\text { Demand } \\
\text { End(Ward) }\end{array}$ & Supply End \\
\hline $\begin{array}{l}\text { Population of } \\
\text { ward }\end{array}$ & Number of OHT's or any other source \\
\hline $\begin{array}{l}\text { Number of } \\
\text { households in } \\
\text { ward }\end{array}$ & Households catered \\
\hline $\begin{array}{l}\text { Water duration in } \\
\text { households }\end{array}$ & $\begin{array}{l}\text { Quantity Water supplied through OHT or } \\
\text { UG reservoir }\end{array}$ \\
\hline
\end{tabular}




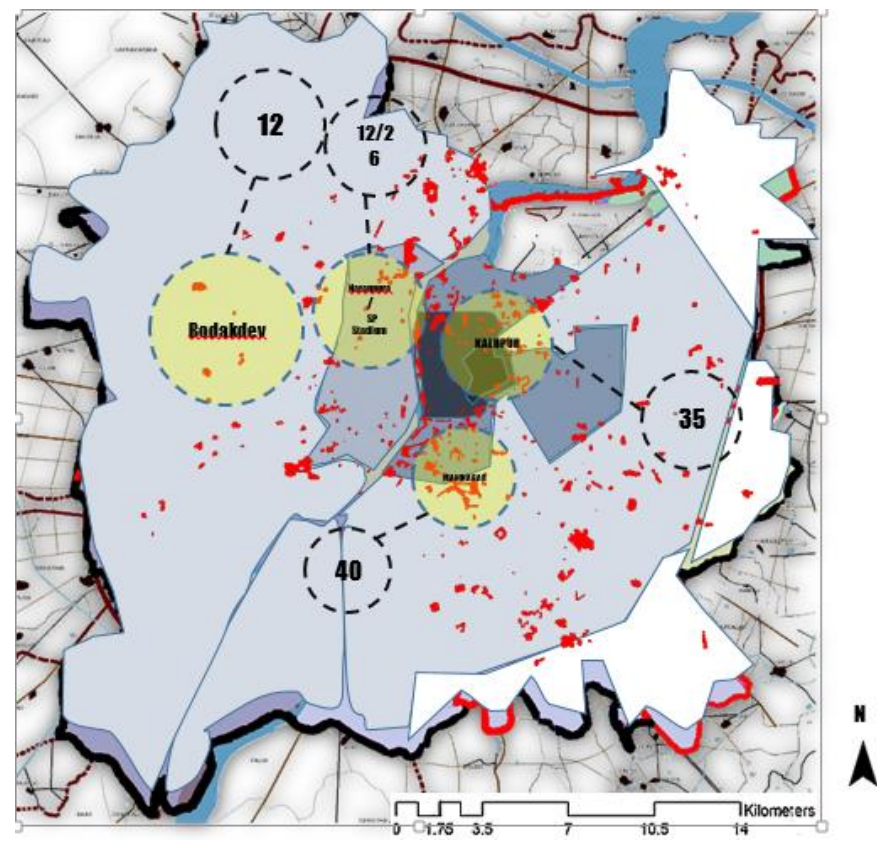

Map 1 : Location of surveyed areas with NRW percentage

A bucket survey was conducted in the above listed locations to estimate the transmission losses and other losses happening in the whole water distribution system. Supply end and demand end were considered in the whole process. After estimating above parameters it was analysed that in the core area of Ahmedabad NRW percentage is maximum whereas in the new west zone it is less. The reason could be the laying of these pipeline network in the old city of Ahmedabad was done before 100-120 years and have not been modified or altered since that time and secondly the location of one of the major water treatment plants i.e. Kotarpur is located far from the old area of Ahmedabad which would have result in huge transmission losses.

\subsection{Strategies to Minimize NRW Percentage?}

Water Auditing and Leak detection survey in the areas of Kalupur and Maninagar where NRW is maximum

Table 3: Ward details with higher NRW

\begin{tabular}{|l|l|l|} 
Ward & $\begin{array}{l}\text { No of } \\
\text { HH }\end{array}$ & Population \\
\hline MANINAGAR & 7339 & 33824 \\
\hline KALUPUR & 11023 & 53630
\end{tabular}

Source: Census of India

As done in many other cities in India like Nagpur etc. Water auditing and Leak detection surveys shall be done in these areas to minimize NRW losses. The whole process of water auditing and Leak detection process is mentioned below with the number of days required for the whole project .The process involve different stages with allocated number of days for the project. The projects shall start with collection of samples from different social backgrounds and getting water distribution network map that should include a list of all isolation valves, hydrants etc.

\subsection{Conceptual understanding of Phases of Project for}

\section{Reducing NRW}

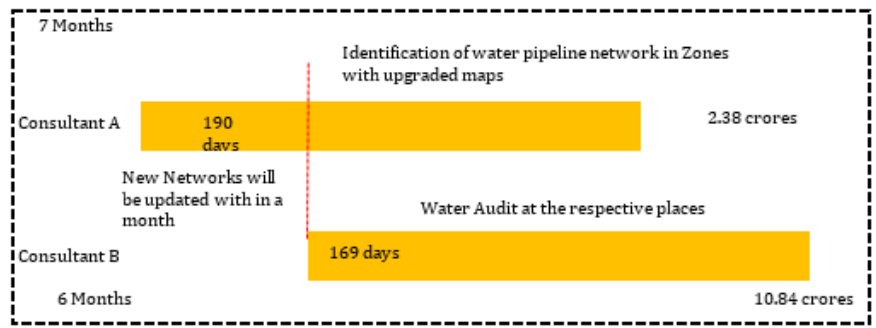

As the information is not updated on the maps in regard to water supply distribution network in Ahmedabad so the primary task is to identify the water distribution network of Ahmedabad including the detail of water hydrants, valves etc. Once the map of water distribution network is generated then it can be used by other private agency to whom the contract for instigating water leak.

\subsection{Water Auditing for Maninagar Ward}

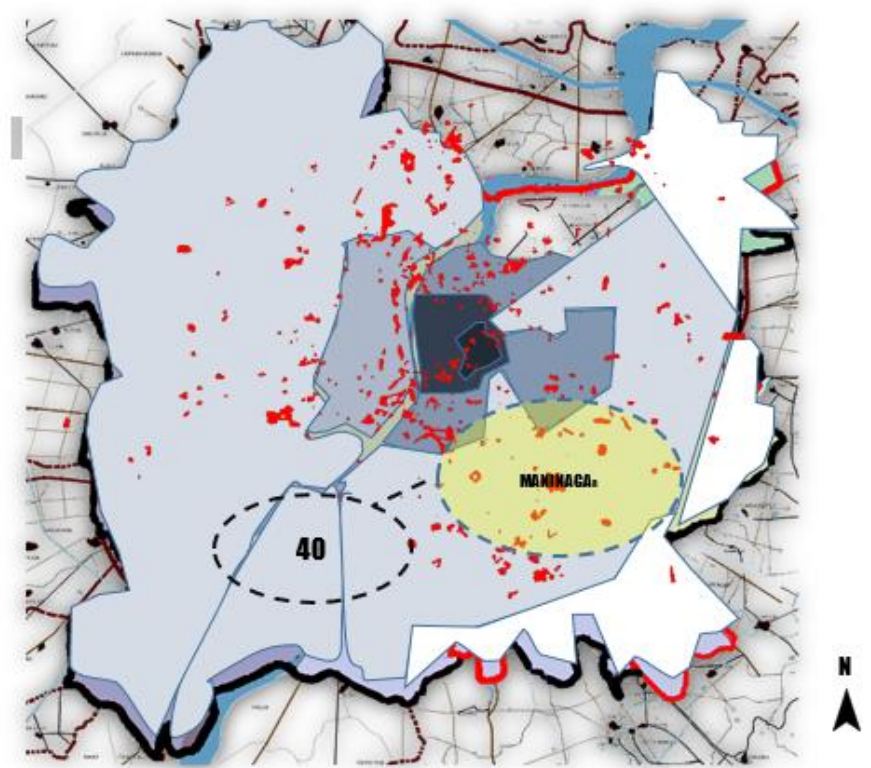

Map 2 : Location of Maninagar with NRW percentage

As a result of bucket survey it was calculated that Maninagar has maximum NRW percentage around 40 percentage thus the people living in Maninagar face water related issues. Thus it is important to take measures to improve the existing condition of Maninagar ward. The aim is to reduce NRW to 26 percent as listed in service level benchmarks developed by MOUD. The pilot project of leak detection include different stages as described

- $\quad$ Selection of samples from MIG,HIG,LIG and slums which will require 11 days

- Availability of Isolation Valves which will require 12 days

- $\quad$ Pipe and valve survey which will require 25 days

- Checking of existing flow which will require 7 days

- Leak detection test which will require 20 days

\section{Overall span of project is $\mathbf{7 5}$ days}




\subsection{Water Auditing for Kalupur Ward}

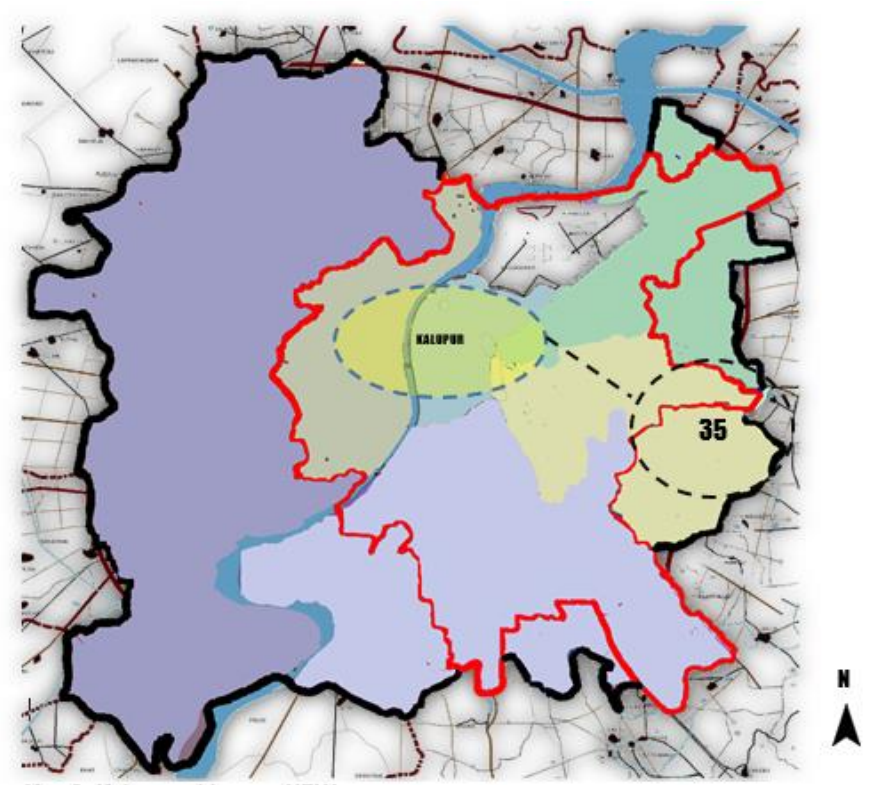

Map 3 : Location of Maninagar with NRW percentage

As a result of bucket survey it was calculated that Kalupur possess more NRW percentage around 35 percentage. Thus it is important to take measures to decrease the NRW percentage of Kalupur ward. The aim is to reduce NRW to 26 percent as listed in service level benchmarks developed by MOUD. The same pilot project of leak detection would be done and it will include different stages as described

- $\quad$ Selection of samples from MIG,HIG,LIG and slums which will require 14 days

- $\quad$ Availability of Isolation Valves which will require 16 days

- $\quad$ Pipe and valve survey which will require 29 days

- $\quad$ Checking of existing flow which will require 11 days

- $\quad$ Leak detection test which will require 24 days

\section{Overall span of project is 94 days}

\section{CONCLUSION}

With the pace of urbanisation, there is a declining trend in delivery of qualitative municipal services in the ULBs. This is a very serious concern in municipal corporations. Where the finances are very inadequate as could be examined from the allocated fund for water sector and the pressure on water services are increasing day by day. The major contributing reason for the poor service delivery is the lack of adequate funds for effective service delivery, resulting in lack of capital funds, poor operation and maintenance of the infrastructure. Moreover there is declining trend in budget allocation to water and sanitation services, in the annual budgets, which can pose a serious challenge to the ULBs for the service enhancement.

The water losses in the state is recorded around 26 per cent which varies among the different ward as can be examined through bucket surveys done at the respective locations.
With the pace of urbanization and depleting trend of ground water reserves as the dependency on ground water is decreasing, there is need for sustainable water management practices, which should come out with a clear policy and then followed by a necessary programme, then only the ULBs can attain mandatory framework for the water management. There is a need for systematic approach for the leakages by mandating the process in regular operation and maintenance practise for a selfsustaining system. Water auditing can be done in the cities having higher NRW percentage and can be reduced by installing bulk meters, SCADA techniques and other systems

\section{REFERENCES}

[1] Aijaz. (2010). Water for Indian Cities: Government Practices and Policy Concerns. Observer Research Foundation, New Delhi

[2] AMC.(2012)City Sanitation Plan, Urban Management Centre

[3] Araral, E (2010). Urban Water Management in Asian Countries: Challenges and Solution. IWA Publishing

[4] Frauendorferc, R and Liemberger, R. (2010). The Issues and Challenges of Reducing Non Revenue Water. ADB publishing.

[5] GoI. (2011). High Powered Expert Committee (HPEC) report on India Urban Infrastructure Services. New Delhi: Government of India.

[6] GoI. (2009). Service Level Benchmarking, Ministry of Urban Development. New Delhi: Government of India.

[7] GoI. (2012). Advisory note on Improving Urban Water Supply and Sanitation Service, Ministry of Urban Development. New Delhi: Government of India.

[8] India Infrastructure Report. (2011). Water: Policy and Performance for Sustainable Development. Oxford University Press, New Delhi.

[9] PwC. (2011). Bringing Water to your door step: Urban Water Reforms for the next decade. PwC

[10] Ranganathan, Kamath, Baindur. (2009). Piped Water Supply to Greater Bangalore: Putting the Cart before the Horse. Economic \& Political Weekly, 15 August.

[11] Registrar General of India. Census of India 2011, Government of India

[12] Water and Sanitation Programme (WSP). (2009). Workshop on Non-Revenue Water Management in Asian South Asia: Issues and Challenges. World Bank

[13] Water and Sanitation Programme (WSP). (2011). Cost Recovery in Urban Water Services: Select Experiences in Indian Cities. World Bank

\section{BIOGRAPHIES}

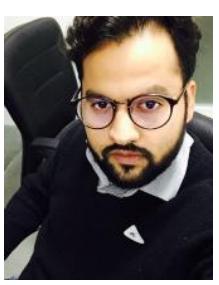

Mr. Vibhore Bakshi is currently working as an Assistant Professor in Architecture and Planning Department, Amity University, Gurgaon 